\title{
Estimation of measurement uncertainty for determination of sulphate content in cement by an alternative approach
}

\section{Ocena merilne negotovosti določanja vsebnosti sulfata v cementu $\mathrm{z}$ alternativnim pristopom}

\author{
Lina Završnik, Sabina Kramar* \\ Slovenian National Building and Civil Engineering Institute, Dimičeva ulica 12, 1000 Ljubljana, Slovenia \\ *sabina.kramar@zag.si
}

\begin{abstract}
The precise and accurate determination of sulphate levels in cement is of utmost importance due to the potential occurrence of internal sulphate attack in concrete, which affects the latter's durability, and thus, also the safety of concrete constructions. The estimated measurement uncertainty provides a level of confidence in the experimental results, and enables the comparison of data, both between different laboratories and between different methods. This paper presents an alternative approach to the estimation of measurement uncertainty in the determination of sulphate in cement, based on the use of proficiency testing data. The calculations used in this procedure refer to the estimation of reproducibility within-laboratory component of the analysis of control samples, as well as of the bias component of sulphate content data for different types of Portland cement derived from several proficiency testing trials.
\end{abstract}

Key words: cement, sulphate, measurement uncertainty, alternative approach
Izvleček

Natančno in točno določanje vsebnosti sulfata $v$ cementu je ključnega pomena predvsem zaradi možnosti nastanka sulfatne korozije $\mathrm{v}$ betonih, kar vpliva na obstojnost in varnost betonskih konstrukcij. Cement je pomemben gradbeni proizvod, ki ga Uredba o gradbenih proizvodih uvršča v najvišjo kategorijo Sistema za ocenjevanje in preverjanje nespremenljivosti lastnosti - Sistem 1+. Vsebnost sulfata v cementu predstavlja ključni parameter, saj njihova količina bistveno vpliva na kvaliteto cementa, na določanje njegove vsebnosti pa vplivajo številni dejavniki. Potreba po primerljivih rezultatih je poudarjena $\mathrm{z}$ vse večjim sprejetjem standardov in sistemov kakovosti, ki določajo, da testni laboratoriji vzpostavijo in vzdržujejo postopke za oceno merilne negotovosti (ISO/IEC 17025). Za oceno merilne negotovosti se lahko uporabljata dva načina, in sicer t.i. pristop od spodaj navzgor (angl. »bottom-up approach «) in od zgoraj navzdol (angl. »top-down approach«). Medtem ko pristop od zgoraj navzdol oz. matematični pristop temelji na prepoznavanju posameznih komponent, ki vlivajo na merilno negotovost, pa pristop od zgoraj navzdol oz. pristop, imenovan tudi alternativni oziroma empirični pristop temelji na podatkih pridobljenih pri znotraj laboratorijskih validacijah in medlaboratorijskih primerjavah, kar omogoča, da so v oceno merilne negotovosti vključeni vsi parametri, ki vplivajo na merilno negotovost in slednja ni podcenjena. Ocenjena merilna negotovost zagotavlja stopnjo zaupanja $\mathrm{v}$ rezultate določanja in omogoča primerjave med rezultati pridobljenimi $v$ različnih laboratorijih kot tudi primerjavo med različnimi metodami meritev. $\mathrm{V}$ članku je predstavljena ocena merilne negotovosti

(c) Br-NC-ND (C) 2016 Lina Završnik, Sabina Kramar, published by De Gruyter Open.

This work is licensed under the Creative Commons Attribution-NonCommercial-NoDerivs 3.0 License. 
določanja sulfata $\mathrm{v}$ cementu $\mathrm{z}$ alternativnim pristopom $\mathrm{z}$ uporabo podatkov iz medlaboratorijskih primerjav. Pri tem postopku izračun temelji na oceni komponente ponovljivosti iz rezultatov določitve vsebnosti sulfata znotraj laboratorija in oceni komponente primerljivosti iz rezultatov določitve vsebnosti sulfata v različnih portlandskih cementih $\mathrm{v}$ medlaboratorijskih primerjavah. Uporabljeni podatki so bili pridobljeni z meritvami štirih kontrolnih vzorcev običajnih portlandskih cementov znotraj laboratorija, ki so bili merjeni v daljšem časovnem obdobju, ter iz šestih zaporednih medlaboratorijskih primerjav, izvedenih na 12 vzorcih sedmih različnih vrst običajnih portlandskih cementov v obdobju treh let. Iz pridobljenih podatkov znotraj laboratorijske validacije smo pridobili standardni odklon za ponovljivost znotraj laboratorija, iz medlaboratorijskih primerjav pa razliko med rezultatom preskušanja laboratorija in sprejeto pravo vrednostjo medlaboratorijske primerjave - bias, prispevek merilne negotovosti sprejete prave $-\mathrm{U}\left(\mathrm{C}_{\text {ref }}\right)$; in natančnost meritve, izvedene na vzorcih medlaboratorijske -RMS bias. Podatki so omogočili nadaljnji izračun kombinirane $\left(\mathrm{u}_{\mathrm{c}}\right)$ in razširjene merilnene gotovosti (U). Izračunana razširjena merilna negotovost vsebnosti sulfata v cementu, ki smo jo določili na podlagi alternativnega pristopa, je enaka $0.15 \%$. Ta vrednost se nahaja znotraj območja merilne negotovosti, opredeljene v standardu EN 196-2. Ocena merilne negotovosti je lahko v veliko pomoč pri uvajanju novih preskusnih metod, pri primerjanju rezultatov različnih metod ali laboratorijev, ali v primeru, ko sta potrebna potrditev in dokaz o zanesljivosti določene preskusne metode.

Ključne besede: cement, sulfat, merilna negotovost, alternativni pristop 


\section{Introduction}

Cement is classified by the Construction Products Regulation - CPR-EU Regulation No. $305 / 2011$ [1] - as a construction material with the highest level of attestation of conformity $(1+)$, with conformity evaluation accomplished in accordance with the scheme outlined in standard EN 197-2 [2]. The latter includes several chemical and physical-mechanical parameters, which are determined according to the procedures described in standard series EN 196 (methods of testing cement).

Among these methods, the precise determination of sulphate content in cement is of the utmost importance because of its crucial impact on the cement quality. Sulphate, most often in the form of gypsum $\left(\mathrm{CaSO}_{4} \cdot 2 \mathrm{H}_{2} \mathrm{O}\right)$, is added to clinker in the manufacture of Portland cement for the purpose of retarding the hydration of aluminate phase [3], and as such, acts in parallel as a regulator of setting time and also influences the cement's ultimate compressive strength [4]. Gypsum addition retards the fast exothermic reaction of tricalcium aluminate $\left(3 \mathrm{CaO} \cdot \mathrm{Al}_{2} \mathrm{O}_{3}\right.$ or $\left.\mathrm{C} 3 \mathrm{~A}\right)$ by forming ettringite $\left(\mathrm{Ca}_{6} \mathrm{Al}_{2}\left(\mathrm{SO}_{4}\right)_{3}(\mathrm{OH})_{12} \cdot 26 \mathrm{H}_{2} \mathrm{O}\right)$ [5], which prevents false setting during concrete production, transfer and placing. However, the addition of an excessive amount of gypsum leads to an abnormal and detrimental expansion of concrete and mortar [4], or to a deterioration due to the internal sulphate attack [6]. Thus, codes such as ASTM C150 [7] and EN 197-1 [8] regulate the maximum level of sulphate expressed as $\mathrm{SO}_{3}$ with respect to durability, although no $\mathrm{SO}_{3}$ minimums are assigned. These norms define the maximum sulphate limits depending on cement type.

The values obtained in the testing of cement, as with those obtained in the testing of most materials, are subject to many variables. As a result, the methods used in performing the tests are carefully specified, as are the requirements and tolerances of the test equipment to be used. However, all analytical procedures are subject to diverse sources of systematic and random errors that may be inherent in the method or related to the working practices employed within laboratories. Any measurement is in reality only an estimate of the true value of the quantity being measured, and should always be accompanied by an estimate of the uncertainty of the measurement [9]. The need for comparable results is underscored by the increasing adoption of standards and measurement quality systems, such as laboratory accreditation following ISO/IEC 17025 [10], which has been widely adopted in the construction sector. The technical requirements of this standard demand that accredited testing laboratories establish and maintain procedures for the assessment of measurement uncertainty, providing quantitative estimates of the level of confidence for test results, and therefore representing an essential component of a quality control system also for cement-testing laboratories. The measurement uncertainty estimation provides a means with which to assess and compare the overall variability of analytical procedures carried out within a single laboratory or within different laboratories, and is an important factor in comparing results with reference values or criteria given in product standards or legislative limits. The International Standards Organisation (ISO), in cooperation with other international bodies, has published a Guide to the Expression of Uncertainty of Measurement (GUM) in order to achieve an international consensus regarding the evaluation and expression of measurement uncertainty [11]. The principles of this guide are currently being adapted for a wide range of measurements, not only in testing and calibration but also with respect to analytical measurements [12]. However, the estimation of measurement uncertainty for specific examples is a complex issue and requires the knowledge of principles of the method, as well as a firm statistical background.

Two types of approaches are generally employed to estimate the uncertainty: the bottom-up approach and the top-down or global approach [13]. The bottom-up approach, also known as the modelling approach, the basic principles of which are defined in the JCGM reference document entitled 'Guide to the Expression of Uncertainty in Measurement-GUM' [11], requires the identification and estimation of each separate source of uncertainty and their combination in order to arrive at an overall uncertainty estimate. This approach may be con- 
sidered unsuitable for cement testing methods, because the latter are subject to many sources of uncertainty, some of which are not effectively quantifiable for any individual experiment. One of the main problems is represented by the complex sample matrix from which arise many influencing parameters; therefore, an alternative approach should be considered. Whereas, the GUM uncertainty framework is based on propagating uncertainties in a first-order approximation to the model of the measurement system (the modelling approach, i.e., the Monte Carlo approach [14]), a top-down estimate of measurement uncertainty, also known as the alternative empirical approach, is usually derived from inter- (inter-laboratory validation approach, proficiency testing approach) or intra-laboratory (single laboratory validation approach) trials in which the trueness, accuracy and precision of laboratory procedures are estimated $[13,15]$. Whereas the modelling approach employed for the evaluation of measurement uncertainty is designed to deliver an estimate of the uncertainty of a measurement result, the results obtained using empirical approaches most often have a different scope, usually referring to a specified test procedure rather than to a specified measurement result [13].

In this study, we present the calculations of measurement uncertainty for sulphate content in cement based on an alternative approach by using proficiency testing data. The data used are obtained from the single laboratory validation, which was defined based on the measurement of four internal control cement samples over a certain period of time, and data from six successive proficiency tests carried out on 12 samples of seven different types of Ordinary Portland Cement collected over three years of participation. While the data from the within-laboratory validation included the within-laboratory reproducibility standard deviation from proficiency testing participation, the deviation of the laboratory results from the assigned value of the proficiency testing sample, an uncertainty component from the nominal value, and the precision of measurement carried out on the proficiency testing sample were obtained. From these data, the combined and expanded uncertainties were calculated.

\section{Materials and methods}

The evaluation of measurement uncertainty for cement sulphate content was based on the proficiency testing approach [13], also referred as the NORDTEST approach [15], using the data obtained via control samples measurement and proficiency testing.

To determine the within-laboratory reproducibility, sulphate content measurements were performed on four control cement samples prepared in the laboratory. The samples consisted of Portland cement clinker and gypsum (CEM I), with added siliceous fly ash (CEM II/ $\mathrm{A}-\mathrm{V})$ and siliceous fly ash and limestone (CEM II/A-M (V-LL); CEM II/B-M (V-L)).

Bias data for sulphate content were derived from proficiency testing carried out twice per year, with the number of participating laboratories ranging between 55 and 70 . In the present study, 12 samples of seven different types of Ordinary Portland Cement collected over three years of participation were used, including the following cement types: CEM I/42.5 R, CEM I/52.5N, CEM I/52.5 R, CEM I 42.5 N-SR 5, CEM II/A-V 42.5 R, CEM II/A-P 42.5 R and CEM II/ A-L 52.5 R. Whereas, CEM I consisted of 95-100 $\%$ clinker, the Portland composite cements contained 6-20\% siliceous fly ash (CEM II/A-V), natural pozzolana (CEM II/A-P), or limestone (CEM II/A-L). The analysed test samples were similar to the routine samples, and were analysed according to the prescribed standardised methods (i.e., those outlined in EN 196), with the results then statistically evaluated.

Sulphate was determined according to SIST EN 196-2:2013, point 4.4.2 [16]. Sulphate ions, produced by the decomposition of cement with hydrochloric acid, were precipitated with a solution of barium chloride. The precipitation of barium sulphate was carried out at boiling point, with the determination then completed gravimetrically, and sulphate expressed as $\mathrm{SO}_{3}$.

\section{Results and discussion}

\section{Determination of sulphate content}

The results of 10 sulphate content measurements carried out over a four-month period are shown in Table 1 for each control sample. Sul- 
Table 1: Results of sulphate content measurements for control sample - cement reference material. $S_{R W}$ : reproducibility withinlaboratory standard deviation.

\begin{tabular}{|c|c|c|c|c|c|c|c|c|c|c|c|c|}
\hline \multirow{2}{*}{ Sample } & \multicolumn{10}{|c|}{ Measurements (\%) } & \multirow{2}{*}{$\begin{array}{c}\text { Average } \\
\text { (\%) }\end{array}$} & \multirow{2}{*}{$\begin{array}{c}\text { Standard } \\
\text { Deviation } \\
(\%)\end{array}$} \\
\hline & 1 & 2 & 3 & 4 & 5 & 6 & 7 & 8 & 9 & 10 & & \\
\hline V-434/9 & 2.47 & 2.50 & 2.51 & 2.55 & 2.50 & 2.47 & 2.56 & 2.50 & 2.52 & 2.55 & 2.51 & 0.03 \\
\hline $\mathrm{V}-435 / 9$ & 2.52 & 2.54 & 2.50 & 2.51 & 2.58 & 2.53 & 2.62 & 2.60 & 2.60 & 2.58 & 2.56 & 0.04 \\
\hline V-436/9 & 2.39 & 2.37 & 2.39 & 2.35 & 2.56 & 2.38 & 2.42 & 2.41 & 2.43 & 2.41 & 2.41 & 0.06 \\
\hline V-287/14 & 2.90 & 2.96 & 3.01 & 3.04 & 3.03 & 3.03 & 3.00 & 3.00 & - & - & 3.00 & 0.05 \\
\hline & & & & & & & & & & & $\operatorname{Rw}(\%)=$ & 0.04 \\
\hline
\end{tabular}

phate content in the analysed cements ranged from $2.35 \%$ to $3.04 \%$, with these values then employed in the calculation of within-laboratory reproducibility.

Sulphate content values for the cement samples used in proficiency testing are shown in Table 2, together with other data obtained from the proficiency trials. Sulphate content in these cements ranged from $3.17 \%$ to $3.68 \%$. Nominal values (accepted reference values or assigned values) for the cements analysed in the proficiency tests, here designated as $\mathrm{X}_{\text {ref' }}$ were derived based on an average of the tested characteristic; outliers were not considered. The definition of an assigned value is usually achieved by calculating mean values from the data (with different methods) or by designating reference laboratories, although neither method is completely satisfactory.

\section{Estimation of measurement uncertainty}

The data utilised in the proposed proficiency testing approach are precision and bias data obtained from within-laboratory validation and proficiency tests, with the within-laboratory reproducibility standard deviation being combined with estimates of method and laboratory bias using proficiency testing data. This method is one of the alternative 'empirical approaches', which have, at least with respect to the more frequently applied inter-laboratory validation approach or single laboratory validation approach, received greater attention only in the last decade or so $[13,17]$. However, while in the modelling approach, major uncertainty contributions may be lacking, input uncertainties may be wrongly estimated and correlations may be overlooked. Empirical approaches are based on whole-method performance investigations, de- signed and conducted so as to account for the effects of as many relevant uncertainty sources as possible [13]. Consequently, measurement uncertainty is often significantly underestimated, as shown in several studies [18]. In the empirical approach, significant effects which have not been included in the experimental design for method performance investigation, such as variations of test items or test conditions, will be missing in a (collaborative or within-laboratory) reproducibility standard deviation [13].

\section{Within-laboratory reproducibility}

For the purpose of obtaining an initial estimate of measurement uncertainty using the proficiency testing approach, the within-laboratory reproducibility standard deviation $\left(\mathrm{S}_{\mathrm{RW}}\right)$ obtained from single-laboratory validation of the measurement procedure was used. The $\mathrm{S}_{\mathrm{RW}}$ value, which can be estimated from the standard deviation of a control sample over a certain period of time $[13,15]$, was defined based on the measurement of four internal control cement samples (Table 1) and the following value was obtained:

$\mathrm{S}_{\mathrm{Rw}}=0.04 \%$

\section{Uncertainty component from proficiency testing}

Data obtained from proficiency testing participation included: (i) the deviation of the laboratory results from the assigned value of the proficiency testing sample - the bias; (ii) an uncertainty estimate of the assigned value $\mathrm{U}\left(\mathrm{C}_{\mathrm{ref}}\right)$; and (iii) the precision of the measurement carried out on the proficiency testing sample - RMS bias. 
Table 2: Proficiency testing results for sulphate content in cement samples. $X_{\text {lab }}$ : represents the result (or the average of the results) reported by a participant for the measurement of the one characteristic of test material in one round of proficiency testing scheme; $X_{\text {ref }}$ assigned value; $n_{\text {lab }}$ : number of participating laboratories; $S_{R}$ reproducibility standard deviation of a measurement (provided by the proficiency testing organiser).

\begin{tabular}{ccccccc} 
Sample & $\begin{array}{c}\mathbf{x}_{\text {lab }} \\
\mathbf{( \% )}\end{array}$ & $\begin{array}{c}\mathbf{x}_{\text {ref }} \\
\mathbf{( \% )}\end{array}$ & $\begin{array}{c}\text { bias }=\mathbf{x}_{\text {lab }}-\mathbf{x}_{\text {ref }} \\
\mathbf{( \% )}\end{array}$ & $\begin{array}{c}\text { bias }^{2} \\
(\mathbf{\% )}\end{array}$ & $\mathbf{n}_{\text {lab }}$ & $\begin{array}{c}\mathbf{S R} \\
\mathbf{( \% )}\end{array}$ \\
\hline $\mathrm{V}-137 / 11$ & 3.66 & 3.71 & -0.05 & 0.0025 & 69 & 0.09 \\
\hline $\mathrm{V}-138 / 11$ & 3.50 & 3.58 & -0.08 & 0.0064 & 67 & 0.08 \\
\hline $\mathrm{V}-600 / 11$ & 3.30 & 3.20 & 0.10 & 0.0100 & 66 & 0.08 \\
\hline $\mathrm{V}-601 / 11$ & 3.17 & 3.13 & 0.04 & 0.0016 & 67 & 0.09 \\
\hline $\mathrm{V}-315 / 12$ & 3.21 & 3.28 & -0.07 & 0.0049 & 63 & 0.08 \\
\hline $\mathrm{V}-316 / 12$ & 3.33 & 3.37 & -0.04 & 0.0016 & 63 & 0.08 \\
\hline $\mathrm{V}-556 / 12$ & 3.37 & 3.35 & 0.02 & 0.0004 & 57 & 0.09 \\
\hline $\mathrm{V}-557 / 12$ & 3.62 & 3.56 & 0.06 & 0.0036 & 57 & 0.08 \\
\hline $\mathrm{V}-267 / 13$ & 3.44 & 3.35 & 0.09 & 0.0081 & 58 & 0.09 \\
\hline $\mathrm{V}-268 / 13$ & 3.48 & 3.51 & -0.03 & 0.0009 & 59 & 0.09 \\
\hline $\mathrm{V}-471 / 13$ & 3.59 & 3.50 & 0.09 & 0.0081 & 62 & 0.11 \\
\hline $\mathrm{V}-472 / 13$ & 2.68 & 2.65 & 0.03 & 0.0009 & 64 & 0.10 \\
\hline & & & & $\boldsymbol{\Sigma}\left(\mathbf{b i a s} \mathbf{j}^{2}\right.$ & Average & Average \\
\hline & & & & $\mathbf{0 . 0 4 9}$ & $\mathbf{6 3}$ & $\mathbf{0 . 0 8 8}$ \\
\hline
\end{tabular}

Accuracy or bias can be defined as the closeness of agreement between an independent test result and the corresponding true value, which is generally unknown and is thus an idealised concept. The bias (difference between mean measured value obtained from a large series of test results and an assigned value) obtained in the present study for 12 samples after three years' participation is shown in Table 2, which reveals a range from $-0.08 \%$ to $0.10 \%$. Furthermore, $\sum$ bias $_{i}^{2}$, calculated from these data, was equal to 0.031 (Table 2). From these data and $\mathrm{n}_{\mathrm{PT}}$ (number of proficiency testing trials), the RMS bias (the root mean square of the bias values) was calculated as follows:

$R M S_{\text {bias }}=\sqrt{\frac{\sum \text { bias }_{i}^{2}}{n_{P T}}}=\sqrt{\frac{0.049}{12}}=0.064 \%$

As can also be seen from Table 2, the standard deviation of the inter-laboratory comparison reproducibility $\left(\mathrm{s}_{\mathrm{R}}\right)$, as provided in proficiency testing reports, was in the range of 0.08 to 0.11 , with the average $s_{R}=0.088 \%\left(n_{\text {lab }}=63\right)$. From these data, we can then calculate an uncertainty component from the certified or nominal values $u\left(\mathrm{C}_{\text {ref }}\right)$, which is, according to the NORDTEST approach, an estimate of an overall average for several rounds $[13,15]$ or the uncertainty of the assigned value. The $\mathrm{u}\left(\mathrm{C}_{\text {ref }}\right)$ value is calculated as follows:

$u\left(C_{r e f}\right)=1.25 \cdot \frac{S_{R}}{\sqrt{n_{\text {lab }}}}=1.25 \cdot \frac{0.088}{\sqrt{63}}$
$u\left(C_{\text {ref }}\right)=0.014 \%$

In cases where the assigned value is a median value, the equation will follow the principles of ISO 13528 [19], be $u\left(C_{\text {ref }}\right)=1.253 \cdot s R / \sqrt{n}$. The factor 1.25 represents the ratio of the standard deviation of median to the standard deviation of arithmetic mean, for large samples $\left(\mathrm{n}_{\mathrm{lab}}>10\right)$ from a normal distribution.

\section{Calculation of the combined and expanded uncertainty}

Before calculating the combined and expanded measurement uncertainty, the components must be converted to standard uncertainty. The reproducibility within-laboratory standard deviation can be accepted as the combined standard uncertainty (u) for chemical analyses according to the alternative approach [13]: 
$u\left(R_{w}\right)=s_{R w}=0.04 \%$

The bias contribution to measurement uncertainty is quantified as follows:

$$
\begin{aligned}
u(\text { bias }) & =\sqrt{R M S_{\text {bias }}^{2}+u\left(C_{\text {ref }}\right)^{2}} \\
& =\sqrt{0.064^{2}+0.014^{2}} \\
u(\text { bias }) & =0.065 \%
\end{aligned}
$$

From the data obtained above, the combined standard uncertainty $\left(u_{c}\right)$ for the estimation of sulphate content in the tested cement samples is calculated as:

$$
\begin{aligned}
& u_{c}=\sqrt{u\left(R_{w}\right)^{2}+u(\text { bias })^{2}}=\sqrt{0.04^{2}+0.065^{2}} \\
& u_{c}=0.077 \%
\end{aligned}
$$

The expanded measurement uncertainty (U) of the result was then calculated by multiplying the combined uncertainty by a coverage factor $\mathrm{k}=2$, which for a normal distribution of the measurand gives a coverage probability of approximately $95 \%$ :

$\mathrm{U}=\mathrm{k} \times \mathrm{u}=2 \times \mathrm{u}_{\mathrm{c}}=2 \times 0.077=$

$\mathrm{U}=0.15 \%$

Along with the expanded measurement uncertainty, the measuring result is given as follows:

Result: ( $\mathrm{x} \pm \mathrm{U}) \cdot$ (unit)

$\mathrm{SO}_{3}$ content: $(\mathrm{x} \pm 0.15) \%$

The expanded uncertainty $U$ is used to provide a level of confidence in the measurement result, and covers an interval expected to include a large fraction of the distribution of values reasonably attributable to the measurand, calculated as $U=k \times u$ with an appropriate factor $\mathrm{k}$ [12].

The estimated measurement obtained through the proficiency testing approach is in the range of the calculated measurement uncertainty for $\mathrm{SO}_{3}$, outlined in standard EN 196-2 [16], which defines the standard deviation for reproducibility $\left(\mathrm{s}_{\mathrm{R}}=0.08 \%\right)$ for an individual measurand. From these data, the expanded measurement uncertainty $(\mathrm{k}=2)$ is calculated as $0.16 \%$.

\section{Conclusions}

The substantial amount of data generated during the course of six successive proficiency tests carried out on 12 samples allowed us to estimate the measurement uncertainty of sulphate content in cement using an alternative approach.

The calculated expanded measurement uncertainty of sulphate content in cement, determined by the alternative approach based on proficiency testing, was found to equal $0.15 \%$. This value lies within the range of calculated measurement uncertainty defined in standard EN 196-2.

The evaluation of measurement uncertainty is important not only because of the requirements of the ISO 17025 standard, but also because it provides a level of confidence in experimental results, and enables a comparison of data from different laboratories, as well as those obtained via different methods. The evaluation of measurement uncertainty can be of great help when introducing new test methods, when comparing the results of different methods or laboratories, or when confirmation and proof as to the reliability of the test method is needed.

\section{Acknowledgements}

This study was financially supported by the Metrology Institute of the Republic of Slovenia.

\section{References}

[1] Regulation (EU) No 305/2011 of the European Parliament and of the Council of 9 March 2011 laying down harmonised conditions for the marketing of construction products and repealing Council Directive 89/106/EEC, Official Journal of the European Union, $43 \mathrm{p}$

[2] EN 197-2:2014: Cement-Part 2: Conformity evaluation.

[3] Lawrence, C.D. (1998): The Constitution and Specification of Portland Cements, In: Hewlett, P.C. (Ed): Lea's Chemistry of Cement and Concrete, London: Arnold, pp. 131-194. 
[4] Tsamatsoulis, D., Nikolakakos, N. (2012): Investigation of Some Basic Parameters Affecting the Optimum Sulfates Content of Cement, In: Balas, V.E., Koksal, M. (Eds.): Recent Researches in Circuits and Systems, Proceedings of the 16th WSEAS International Conference on Circuits and Systems, Kos Island, Greece. WSEAS Press, pp. 152-157.

[5] Odler, I. (1998): Hydration, setting and hardening of Portland cement, In: Hewlett, P.C. (Ed): Lea's Chemistry of Cement and Concrete, London: Arnold, pp. 260-263.

[6] Scrivener, K., Skalny, J. (2004): International RILEM Workshop on Internal Sulfate Attack and Delayed Ettringite Formation. Proceedings pro035: International RILEM Workshop on Internal Sulfate Attack and Delayed Ettringite Formation, 316 p.

[7] ASTM C150-07 Standard Specification for Portland Cement.

[8] EN 197-1: 2011: Cement. Composition, specifications and conformity criteria for common cements.

[9] Stutzman, P., Heckert, A., Tebbe, A., Leigh, S. (2014): Uncertainty in Bogue-calculated phase composition of hydraulic cements. Cement and Concrete Research, 61-62, 40-48.

[10] ISO/IEC 17025/2007: General requirements for the competence of testing and calibration laboratories.

[11] Guide To The Expression Of Uncertainty In Measurement. ISO: Geneva (1993).

[12] (ISBN 92-67-10188-9) (Reprinted 1995: Reissued as ISO Guide 98-3 (2008), also

[13] Available from http://www.bipm.org as JCGM 100:2008)
[14] EURACHEM/CITAT Guide CG4, Quantifying Uncertainty in Analytical Measurements. EURACHEM: Teddington, $3^{\text {rd }}$ Edition, Ellison, S.L.R, Williams, A. (eds), 2012, 135 pp.

[15] EUROLAB Technical Report No. 1/2007 (2007): Measurement uncertainty revised: alternative approaches to uncertainty evaluation. Available on: http:// www.eurolab.org/documents/Technical_Report_ Measurement_Uncertainty_2007.pdf.

[16] Uusitalo, L., Lehikoinen, A., Helle, I., Myberg, K. (2015): An overview of methods to evaluate uncertainty of deterministic models in decision support. Environmental Modelling \& Software, 63, pp. 24-31.

[17] NT Technical report (2012): A handbook for calculation of measurement uncertainty in environmental laboratories. NORDTEST, pp. 46.

[18] EN 196-2:2013, Methods of testing cement - Part 2: Chemical analysis of cement

[19] Jarvis, B., Corry, J.E.L., Hedges, A.J. (2007): Estimates of measurement uncertainty from proficiency testing schemes, internal laboratory quality monitoring and during routine enforcement examination of foods. Journal of Applied Microbiology, 103, pp. 462-467.

[20] Lyn, J.A., Ramsey, M.H., Damant, A.P., Wood, R. (2007): Empirical versus modelling approaches to the estimation of measurement uncertainty caused by primary sampling. Analyst, 132, pp. 1231-1237.

[21] ISO 13528, Statistical methods for use in proficiency testing by inter-laboratory comparison. 